УДК 371. 315: $811.111(043.5)$

\title{
ЕКСПЕРИМЕНТАЛЬНА ПЕРЕВІРКА ЕФЕКТИВНОСТІ МЕТОДИКИ НАВЧАННЯ МАЙБУТНІХ ДИЗАЙНЕРІВ АНГЛОМОВНОГО МОНОЛОГУ-ПРЕЗЕНТАЦЇ̈
}

\author{
Корнсєва I. O. \\ connector0014@gmail.com \\ Київський національний лінгвістичний університет \\ Київський наиіональний університет технології та дизайну
}

Дата надходження 03.04.2018. Рекомендовано до друку 20.04.2018.

\begin{abstract}
Анотація. Стаття грунтується на результатах аналізу робіт учених-методистів, присвячених навчанню монологічного мовлення, зокрема монологу-презентації. Розглянуго ефективність розробленої методики навчання майбутніх дизайнерів професійно орієнтованого англомовного монологу-презентації-доповіді і монологу-презентації-реклами за двома іiї варіантами. Представлено методичний експеримент, проведений з метою перевірки ефективності цієї методики, та доведено доцільність ії впровадження в процес навчання. Наведено завдання та етапи експерименту. Грунтуючись на результатах аналізу опитування викладачів і студентів українських закладів вищої освіти, теоретичного підгрунтя, здійсненого експериментального навчання, ми визначили дані передекспериментального і післяекспериментального зрізів. Інтерпретовано результати експерименту за допомогою математичного аналізу. Зроблено висновок і доведено ефективність двох методик: варіант А $\epsilon$ найефективнішим для навчання монологупрезентації-доповіді, варіант Б - найефективнішим для навчання монологу-презентації-реклами. На основі отриманих даних підтверджено результативність кожного з варіантів методики відповідного монологупрезентації та доцільність їх упровадження в процес навчання.

Ключові слова: професійно орієнтоване навчання, монолог-презентація-доповідь, монолог-презентаціяреклама, експериментальне навчання, завдання та етапи експерименту, варіанти методики, майбутні дизайнери, заклади вищої освіти.
\end{abstract}

Корнеева И. А. Киевский национальный университет технологий и дизайна, Киевский национальный лингвистический университет

Экспериментальная проверка эффективности методики обучения будущих дизайнеров англоязычному монологу-презентации

Статья основывается на результатах анализа работ ученых-методистов, посвященных обучению монологическому высказыванию, в частности монологу-презентации. Рассмотрена эффективность разработанной методики обучения профессионально ориентированному англоязычному монологупрезентации-докладу и монологу-презентации-рекламе будущих дизайнеров по двум ее вариантам. Представлен методический эксперимент, проведенный с целью проверки эффективности данной методики. Доказана необходимость внедрения разработанной методики в учебный процесс. Описаны задания и этапы эксперимента. Основываясь на результатах анализа опроса преподавателей и студентов украинских учебных заведений, теоретической базы, а также проведенного эспериментального обучения, мы определили данные передэкспериментального и послеэкспериментального срезов. Интерпретированы результаты эксперимента с помощью математического анализа. Сделан вывод и доказана эффективность двух методик: вариант А оказался эффективным для обучения монологупрезентации-докладу, вариант Б - для обучения монологу-презентации-рекламы. На основе полученных данных подтверждена результативность каждого варианта методики в соответствии с обучением монолога-презентации, а также необходимость их внедрения в учебный процесс.

Ключевые слова: профессионально ориентированное обучение, монолог-презентация-доклад, монологпрезентация-реклама, экспериментальное обучение, задачи и этапы эксперимента, варианты методики, будущие дизайнеры, заведения высшего образования.

Korneeva I. The Kyiv National Linguistic University, The Kyiv national university of technologies and design Experimental validation of prospective designers English monologue-presentation training method's effectiveness

Abstract. Introduction. In the conditions of the world constant development the second language personality becomes the greatest demand of the society and its future specialists. Therefore, the task of modern languages training is the foreign language communicative competence formation of the students, in particular, the 
possession of its aspect - monologue utterance. The analysis of the last investigations and publications proved that during the last ten years the scientists elaborated and valiedated the effectiveness of different methods and aids for teaching monologue, in particular, monologue-presentation. However, despite the increasing interest of the scientists to this problem, there is the lack of professional oriented English language monologue-presentation training methods for prospective designers. Purpose. Thus, the article purpose consists in researching of profession oriented English language monologue-presentation methodic of future designers and in analysis and interpretation of its results. Methods. To specify the tasks and stages of the methodological experiment, to validate methodic effectiveness we have studied and analyzed a number of scientific publications, researched pre- and post- testing, analyzed the results of the experimental training, used mathematical statistics methods. Results. Testing the effectiveness has given us the possibilities for proving the results of the experiment. It is said, that elaborated training method for teaching monologuepresentation-report and monologue-presentation-advertisement appeared to be the best for developing students' skills to produce the English language monologue-presentation. Questionnaire of the pre-service designers and their tutors of Ukrainian higher education institutions, experimental watching at the beginning of the experimental training has shown that the prospective designers produced their monologue-presentation unconsciously. Therefore, during the experimental training we introduced monologue-presentation problem, connectors, monologue-presentations samples etc. During experimental training we were watching the dynamic of the exercise system fulfillment. That gave the students the possibility to compensate the lack of knowledge, to develop the skills to use connectors, conscious logical-structure of monologue-presentation, to overcome language barrier. Conclusion. The experiment has proved the effectiveness of proposed training method for the profession-oriented English language monologue-presentation competence formation of prospective designers. It could be recommended for implementing into education process. Proposed exercise system consists of tests, tasks with interactive technologies and makes it possible for students to overcome the language barrier. Monologue-presentation increases the motivation, creativity, conscious activity of the students and is the definite step for their earliest profession-oriented activity.

Key words: profession-oriented training, monologue-presentation-report, monologue-presentation-advertisement, experimental training, tasks and stages of experiment, methodic variants, future designers, higher educational institutions.

Постановка проблеми. В умовах постійного світового розвитку вторинна мовна особистість стає потребою освітнього простору суспільства і його майбутнього фахівця. Тому метою сучасного навчання іноземних мов $є$ формування в студентів іншомовної комунікативної компетентності, зокрема оволодіння їі складовою - монологічним мовленням (MМ).

Ця проблема досліджувалася ученими-методистами (Ю. Авсюкевич, А. Алхазішвілі, О. Асадчих, Н. Бичкова, Л. Бондар, Н. Бориско, В. Бухбіндер, О. Васильєва, А. Виселко, Н. Долгалова, Н. Драб, Г. Запорожченко, І. Кіндрась, Г. Китайгородська, О. Леонтьєв, М. Ляховицький, О. Нечаєва, Ю. Пассов, О. Петращук, Ю. Петрусевич, І. Самойлюкевич, В. Скалкін, Н. Соловйова, ін.)

Аналіз останніх досліджень і публікацій свідчить, що в останні десять років науковці дослідили і перевірили ефективність різних методів і прийомів навчання такого виду ММ, як монолог-презентація. Так, франкомовному монологу-презентації було присвячено роботу Л. Бондар (2013) (суб'єкт дослідження - студенти технічних спеціальностей), німецькомовному Н. Драб (2005) (суб'єкт дослідження - майбутні економісти), англомовному - Я. Дьячкової (2015) (суб'єкт дослідження - майбутні правознавці), Ю. Петрусевич (2014) (суб'єкт дослідження - майбутні вчителі іноземної мови).

Однак, незважаючи на значний інтерес до проблеми навчання монологу-презентації майбутніх фахівців, серед науково-методичних досліджень бракує даних 3 методики навчання майбутніх дизайнерів професійно орієнтованого монологу-презентації-доповіді й -реклами й даних її експериментальної перевірки.

Отже, мета статті полягає в дослідженні перевірки ефективності методики навчання майбутніх дизайнерів професійно орієнтованого англомовного монологу-презентації-доповіді й -реклами, а також в аналізі та інтерпретації ії результатів.

Основні результати дослідження. 3 метою підготовки до експериментальної перевірки методики навчання майбугніх дизайнерів професійно орієнтованого англомовного монологу- 
презентації ми провели опитування 30-ти викладачів кафедри іноземних мов КНУТД та 26-ти студентів-дизайнерів 3-го курсу КНУТД. Результати опитування викладачів засвідчили, що 83, 3 \% опитуваних вважають необхідним починати навчання іншомовного монологупрезентації з першого курсу навчання у закладі вищої освіти та лише 16,6 \% висловили думку, що бажано навчати студентів іншомовного монологу-презентації 3 3-4-го курсів, коли починається професійно орієнтоване навчання. 93,3 \% опитуваних підтвердили зв'язок професійно орієнтованого навчання IM з навчанням іншомовного монологу-презентації та $100 \%$ респондентів вважають важливим професійно орієнтоване навчання IМ. При цьому 100-відсотковою $\epsilon$ відповідь викладачів щодо важливості навчати студентів іншомовного монологу-презентації. При цьому вони зізнаються, що не мали (46 \%) досвіду навчання, як робити презентацію. Певні труднощі при цьому відчувають 56, 66 \%.

Мета опитування студентів-дизайнерів 3-го курсу КНУТД полягала у з'ясуванні рівня сформованості їхніх умінь робити іншомовну усну презентацію. Результати опитування продемонстрували, що 66,66 \% опитуваних ніколи не робили презентацію-доповідь або презентацію-рекламу англійською мовою. 95 \% показали, що вони відчувають страх перед аудиторією під час проведення ними англомовної презентації. 75 \% вважають, що не мають достатнього рівня англійської мови для того, щоб провести презентацію. 95, 83\% акцентують, що є необхідним використання зображальної наочності в презентації. 83,33 \% наголошують на необхідності оволодіти вмінням робити усну англомовну презентацію тому, що ці вміння будуть конче важливими для їхньої майбутньої професійної діяльності. При цьому 62,50 \% опитуваних не знають, як структурувати монолог-презентацію, 50 \% не знають, як забезпечити логічні зв'язки між іiі частинами, 54,16 \% не знають напевно, як закінчити презентацію та запросити слухачів до дискусії; 54, 16 \% - як звернутись до англомовної аудиторії.

Отже, опитування студентів-дизайнерів 3-го курсу КНТД показало, що: 1) 75 \% опитуваних вважають, що не мають достатнього рівня англійської мови для того, щоб провести презентацію. Тому ми вбачаємо необхідним розпочинати навчання професійно орієнтованого англомовного монологу-презентації не раніше, ніж на 3-4-му курсах, коли: а) загальний рівень англійської мови В2 досягнутий; б) існують міждисциплінарні зв'язки професійно орієнтованого навчання; 2) $95 \%$ опитуваних продемонстрували, що вони відчувають страх перед аудиторією та певні труднощі під час проведення ними англомовної презентації. Тож, метою нашого експерименту вважаємо підтвердити ефективність розробленої методики навчання майбутніх дизайнерів професійно орієнтованого англомовного монологу-презентації-доповіді, монологу-презентаціїреклами; 3) 87,50 \% опитуваних майбутніх дизайнерів вважають необхідним наявність заняття 3 підготовки англомовної ділової презентації в курсі навчання англійської мови. Тому ми підтверджуємо важливість нашої методики та в експерименті доводимо іiі ефективність і доцільність впровадження в процес навчання.

Проведений методичний експеримент містив такі етапи: 1) підготовка експерименту; 2) проведення експерименту; 3) констатація та інтерпретація його результатів; 4) формулювання висновків та надання методичних рекомендацій щодо розробленої методики, ефективність якої була підтверджена експериментом.

За теорією П. Б. Гуревича (1980), підготовчий етап експерименту передбачає його організацію: визначення об’єкта, предмета й мети експерименту, формулювання гіпотези, розроблення експериментальних матеріалів, відбір учасників експерименту.

Отже, об'єктом експериментального дослідження є перевірка запропонованого нами комплексу вправ для професійно орієнтованого навчання англомовного монологу-презентації майбутніх дизайнерів.

Предметом визначено розвиток навичок і вмінь професійно орієнтованого говоріння (монолог-презентація-доповідь, монолог-презентація-реклама) майбутніх дизайнерів.

Мету експерименту вбачаємо у перевірці ефективності цієї методики і порівнянні результативності навчання за двома їі варіантами.

Теоретичні положення розробленої методики професійно орієнтованого навчання студентів- 
дизайнерів англомовного монологу-презентації стали підгрунтям розроблення та формулювання такої гіпотези експерименту: досягти належного рівня продукування монологу-презентації можливо за таких умов: 1) застосування професійно орієнтованого навчання монологупрезентації згідно з етапами навчання, що уможливить формування навичок і вмінь монологупрезентації майбугніх дизайнерів; 2) добір необхідного навчального матеріалу та здійснення навчання на основі спеціально розробленого комплексу вправ і залучення до нього професійно орієнтованих ігор, пропедевтичних і тестових завдань, скерованих на отримання спеціальних знань щодо побудови монологу-презентації; 3) вибір оптимального варіанта організації професійно орієнтованого навчання монологу-презентації майбутніх дизайнерів.

При цьому в процесі експерименту було перевірено два варіанти методики навчання професійно орієнтованого англомовного монологу-презентації з різною послідовністю вправ: 1) варіант А - навчання монологу-презентації (“зверху - вниз”) починається з вправ на формування вмінь аналізувати та структурувати текст зразка монологу-презентації, мінімонологу, понадфразової єдності; продукувати логіко-зв'язний текст монологу-презентації; 2) варіант Б - навчання монологу-презентації (“знизу - вверх") починається з вправ на формування понадфразової єдності, міні-монологів, тексту монологу-презентації.

Таким чином, варійованою величиною експерименту була послідовність виконання студентами вправ для навчання професійно орієнтованого англомовного монологу-презентації: варіант А (“зверху - вниз”), варіант Б (“знизу - вверх”).

Проведений експеримент був відкритим, природним, (варіантним) горизонтальним і вертикальним. Вертикальний характер експерименту дав змогу виявити загальну ефективність розробленої методики 3 порівнянням рівня розвитку вмінь учасників експерименту продукування монологу-презентації до і після експериментального навчання. Горизонтальний характер експерименту дав змогу перевірити ефективність двох варіантів методики навчання професійно орієнтованого англомовного монологу-презентації майбутніх дизайнерів.

На основі сформульованої вище гіпотези передбачаємо такий наслідок: у результаті використання запропонованої методики навчання професійно орієнтованого англомовного монологу-презентації майбутніх дизайнерів їхній рівень сформованості вмінь продукування монологу-презентації-доповіді й -реклами досягне та перевищить умовний коефіцієнт навченості 0,7 за В. П. Беспальком (1968).

3 огляду на сформульовану мету визначено такі завдання: 1) провести усний та письмовий передекспериментальний зрізи для визначення вихідного рівня сформованості вмінь створення монологу-презентації; 2) проаналізувати результати проведеного опитування та передекспериментального зрізу та порівняти експериментальні групи (ЕГ-1, ЕГ-2) щодо рівня володіння студентами вміннями продукувати монолог-презентацію з метою визначення можливості проведення експериментального навчання; 3) провести експериментальне навчання на основі розробленої методики професійно орієнтованого навчання англомовного монологупрезентації-доповіді й -реклами; 4) провести усний та письмовий післяекспериментальні зрізи для визначення досягнугого рівня сформованості вмінь продукування монологу-презентаціїдоповіді й -реклами; 5) інтерпретувати результати післяекспериментального зрізу та порівняти ефективність двох варіантів запропонованої методики професійно орієнтованого навчання англомовного монологу-презентації-доповіді й -реклами (варіант А, варіант Б); 6) сформулювати висновки щодо ефективності розробленого комплексу вправ, а також оптимального варіанта розробленої методики.

Експеримент проводився у два терміни: 1) з 8. 09. 2017 р. по 25. 12. 2017 р. (навчання монологу-презентації-доповіді); 2) з 12. 03. 2018 р. по 25. 06. 2018 р. (навчання монологупрезентації-реклами), кожний з яких здійснювався у п'ять етапів.

Учасниками експерименту були 26 студентів-дизайнерів 3-го курсу КНУТД, організованих у дві експериментальні групи ЕГ-1, ЕГ-2.

У табл. 1 наведено структуру експериментального навчання монологу-презентації-доповіді 
й -реклами.

Табличя 1

Структура експериментального навчання студентів-дизайнерів монологу-презентації

\begin{tabular}{|c|c|c|c|}
\hline $\begin{array}{c}\text { Дата } \\
\text { проведення }\end{array}$ & $\begin{array}{c}\text { Етап } \\
\text { експериментального } \\
\text { навчання }\end{array}$ & $\begin{array}{c}\text { Кількість } \\
\text { годин } \\
\text { на групу }\end{array}$ & $\begin{array}{c}\text { Основні } \\
\text { завдання етапу }\end{array}$ \\
\hline $\begin{array}{l}\text { 8. 09. } 2017 \mathrm{p.} \\
\text { 15. 09. } 2017 \mathrm{p} . \\
\text { (м.-пр.-доповідь) } \\
\text { 12. 03. } 2018 \mathrm{p.} \\
\text { 19.03. } 2018 \mathrm{p} . \\
\text { (м.-пр.-реклама) }\end{array}$ & $\begin{array}{l}\text { Письмовий } \\
\text { передекспериментальний } \\
\text { зріз }\end{array}$ & 2 год & $\begin{array}{l}\text { Визначити вихідний рівень знань } \\
\text { лексичного, граматичного матеріалу, } \\
\text { знань засобів понадфразового } \\
\text { зв’язку, здатності відновлювати } \\
\text { логіко-структурну композицію } \\
\text { тексту }\end{array}$ \\
\hline $\begin{array}{l}\text { 15. 09. } 2017 \text { р. } \\
\text { 22. 09. } 2017 \text { р. } \\
\text { (м.-пр.-доповідь) } \\
\text { 19. 03. } 2018 \text { р. } \\
\text { 26. 03. } 2018 \text { р. } \\
\text { (м.-пр.-реклама) }\end{array}$ & $\begin{array}{l}\text { Усний } \\
\text { передекспериментальний } \\
\text { зріз }\end{array}$ & 2 год & $\begin{array}{l}\text { Визначити вихідний рівень } \\
\text { сформованості вмінь продукування } \\
\text { монологу-презентації-доповіді, } \\
\text { монологу-презентації-реклами }\end{array}$ \\
\hline $\begin{array}{l}\text { 22. 09. } 2017 \text { p. } \\
\text { 11. 12. } 2017 \text { p. } \\
\text { (м.-пр.-доповідь) } \\
\text { 2. 04. } 2018 \text { p. } \\
\text { 18. 06. } 2018 \text { p. } \\
\text { (м.-пр.-реклама) }\end{array}$ & $\begin{array}{l}\text { Експериментальне } \\
\text { навчання }\end{array}$ & 12 год & $\begin{array}{l}\text { Перевірити ефективність двох } \\
\text { варіантів методики навчання }\end{array}$ \\
\hline $\begin{array}{l}\text { 11. 12. } 2018 \mathrm{p} . \\
\text { 18. 12. } 2018 \mathrm{p} . \\
\text { (м.-пр.-доповідь) } \\
\text { 18. 06. } 2018 \mathrm{p.} \\
\text { 25. 06. } 2018 \mathrm{p} . \\
\text { (м.-пр.-реклама) }\end{array}$ & $\begin{array}{l}\text { Письмовий } \\
\text { післяекспериментальний } \\
\text { зріз }\end{array}$ & 2 год & $\begin{array}{l}\text { Визначити досягнутий рівень } \\
\text { розвитку вмінь створювати монолог- } \\
\text { презентацію, вмінь виражати } \\
\text { особисте ставлення до фактів, } \\
\text { аргументів; критичної оцінки } \\
\text { фактів, наслідків; засвоєння } \\
\text { штампів, засобів понадфразового } \\
\text { зв’язку, притаманних монологу- } \\
\text { презентації }\end{array}$ \\
\hline $\begin{array}{l}\text { 8. 12. } 2017 \text { p. } \\
\text { 25. 12. } 2018 \text { p. } \\
\text { (м.-пр.- } \\
\text { доповідь) } \\
\text { 22. 06. } 2018 \text { p. } \\
\text { 25. 06. } 2018 \text { p. } \\
\text { (м.-пр.-реклама) }\end{array}$ & $\begin{array}{l}\text { Усний } \\
\text { післяекспериментальний } \\
\text { зріз }\end{array}$ & 2 год & $\begin{array}{l}\text { Визначити досягнутий рівень } \\
\text { сформованості вмінь продукування } \\
\text { монологу-презентації-доповіді, } \\
\text { монологу-презентації-реклами }\end{array}$ \\
\hline
\end{tabular}

Розглянемо кожен з етапів експерименту. 8. 09. 2017 р. - 15. 09. 2017 р. ми провели 
письмовий передекспериментальний зріз, який тривав 2 години. Його метою було визначення вихідного рівня знань лексичного, граматичного матеріалу, знань засобів понадфразового зв'язку, здатності відновлювати логіко-структурну схему тексту. Передекспериментальний письмовий зріз складався з трьох частин. Перший тест множинного вибору конекторів понадфразового зв'язку продемонстрував, що лише 8,33 \% студентів (“відмінно”) мають апріорні чи інтуїтивні навички вживання маркерів синтаксичних понадфразових зв”язків. “Добре” орієнтуються в цих зв'язках 33,33 \%, “задовільно” - 33,33 \% та “погано” - 16,66 \%. Середній коефіцієнт навченості студентів вживати конектори понадфразового зв’ язку становив 0,55.

Другий тест мав на меті перевірку вмінь відновлювати порушену логіку викладу матеріалу, розпізнавати логіко-структурні складові тексту; здатності орієнтуватися у причиннонаслідкових зв'язках тексту. Аналіз результатів тесту виявив, що на “відмінно” виконали тест 0 \% студентів, на “добре" - 25 \%, на "задовільно" - 50 \% та “погано" - 25 \%. Результати демонструють, що студенти не знайомилися раніше 3 логічною структурою побудови висловлювань, не мають свідомих знань причинно-наслідкових зв'язків між частинами тексту та маркерів, що встановлюють ці зв'язки. Середній коефіцієнт навченості за результатами другого тесту становив 0,35, що визначило специфіку завдань в експериментальному навчанні та підтвердило необхідність розроблення дотичної методики навчання.

Трете завдання передекспериментального тесту мало на меті виявити знання студентів щодо побудови монологу-презентації, умінь встановити зв'язки між частинами створюваного тексту, умінь вживати конектори понадфразового зв'язку, щоб покращити інформування, аргументацію, переконання, вмотивування слухачів, аудиторії, клієнтів тощо.

"Відмінно" отримали 16,66 \% студентів, “добре" - 16,66 \%, “задовільно" - 33,33 \%, “погано” - 33,33 \% (у тому числі відмовились від виконання тестового завдання тому, що не мали знань й упевненості, як це зробити). Низькі показники цього тесту демонструють, що студенти технічного закладу вищої освіти на 3-му курсі навчання мають страх, певні труднощі у створенні монологу-презентації, не мають взагалі досвіду, як це зробити англійською мовою. Середній коефіцієнт навченості за результатами третього тесту склав 0,43 .

Отже, низькі результати письмового передекспериментального зрізу підтвердили актуальність нашого дослідження і доцільність проведення спеціального навчання студентів створенню монологу-презентації-доповіді й -реклами.

Усний передекспериментальний зріз, який тривав 2 години, був орієнтований на виявлення рівня сформованості у студентів умінь продукувати монолог-презентацію-доповідь й -рекламу. Результати усного передекспериментального зрізу виявили, що середній коефіцієнт навченості у студентів створювати монолог-презентацію-доповідь склав в ЕГ-1 - 0,38, в ЕГ-2 - 0,42; монолог-презентацію-рекламу - в ЕГ-1 - 0,48, в ЕГ-2 - 0,52. Усі монологи студентів записувалися на диктофон й оброблялися за критеріями оцінювання рівня сформованості вмінь створювати монолог-презентацію-доповідь й -рекламу.

Дані письмового й усного передекспериментального зрізів стали підгрунтям проведення експериментального навчання. У табл. 2 наведено структуру навчання професійно орієнтованого монологу-презентації.

Таблиця 2

Структура навчання професійно орієнтованого монологу-презентації

\begin{tabular}{|c|c|c|c|}
\hline $\begin{array}{c}\text { Теми практичних } \\
\text { занять }\end{array}$ & $\begin{array}{c}\text { Мета } \\
\text { практичного заняття }\end{array}$ & $\begin{array}{c}\text { Кількість } \\
\text { аудиторних } \\
\text { годин }\end{array}$ & $\begin{array}{c}\text { Форма } \\
\text { контролю }\end{array}$ \\
\hline $\begin{array}{l}\text { 1. Theoretical overview. } \\
\text { Scheme of presentation. } \\
\text { The importance of clear } \\
\text { organization }\end{array}$ & $\begin{array}{l}\text { Students should be able to: elaborate } \\
\text { an introduction, a body, a conclusion, } \\
\text { an ending, an question-answer and } \\
\text { discussion period; deal with criticism, } \\
\text { manage conflicts }\end{array}$ & 2 год & $\begin{array}{c}\text { Усне } \\
\text { вибіркове } \\
\text { опитування }\end{array}$ \\
\hline
\end{tabular}




\begin{tabular}{|c|c|c|c|}
\hline & & \multicolumn{2}{|c|}{ Продовження табл. 2} \\
\hline $\begin{array}{l}\text { 2. Types of presentations: } \\
\text { informative, persuasive, } \\
\text { inspirational, entertaining } \\
\text { Developing presentation }\end{array}$ & $\begin{array}{l}\text { Students should be able to: have a clear } \\
\text { idea what a business presentation they } \\
\text { have to create; categorize presentations } \\
\text { according to their purpose; formulate } \\
\text { the thesis of their presentation; organize } \\
\text { the presentation }\end{array}$ & 2 год & $\begin{array}{c}\text { Усне } \\
\text { вибіркове } \\
\text { опитування }\end{array}$ \\
\hline $\begin{array}{l}\text { 3. Transitional } \\
\text { expressions and signposts, } \\
\text { their importance in } \\
\text { presentation }\end{array}$ & $\begin{array}{l}\text { Students should be able to: develop an } \\
\text { introduction, a body, a conclusion and } \\
\text { an ending according to transitional } \\
\text { expressions and signposts; analyze } \\
\text { their usage }\end{array}$ & 2 год & $\begin{array}{c}\text { Усне } \\
\text { вибіркове } \\
\text { опитування }\end{array}$ \\
\hline $\begin{array}{l}\text { 4. Style, verbal and non- } \\
\text { verbal means of } \\
\text { presentation support }\end{array}$ & $\begin{array}{l}\text { Students should be able to: use vivid } \\
\text { verbal and non-verbal language in their } \\
\text { presentation and improve their skills } \\
\text { and technique }\end{array}$ & 2 год & $\begin{array}{c}\text { Усне } \\
\text { вибіркове } \\
\text { опитування }\end{array}$ \\
\hline $\begin{array}{l}\text { 5. Monologue- } \\
\text { presentation-report }\end{array}$ & $\begin{array}{l}\text { Students should be able to: develop } \\
\text { their speech topic, analyze their } \\
\text { audience and adapt their report } \\
\text { message to their audience, effectively } \\
\text { use visual aids to assist them }\end{array}$ & 2 год & $\begin{array}{c}\text { Усне } \\
\text { вибіркове } \\
\text { опитування }\end{array}$ \\
\hline $\begin{array}{l}\text { 6. Monologue- } \\
\text { presentation- } \\
\text { advertisement }\end{array}$ & $\begin{array}{l}\text { Students should be able to: develop } \\
\text { their speech topic, use body language } \\
\text { transitions effectively to inform, persuade, } \\
\text { inspire the audience, partners, clients, } \\
\text { to influence their mutual benefits, } \\
\text { decisions and support in promoting the } \\
\text { service, production, goods etc. }\end{array}$ & 2 год & $\begin{array}{c}\text { Усне } \\
\text { вибіркове } \\
\text { опитування }\end{array}$ \\
\hline
\end{tabular}

Після експериментального навчання в ЕГ-1 і ЕГ-2 студентам був наданий зразок монологу-презентації. На підсумковому етапі експериментального навчання за розробленою методикою проведено усний і письмовий післяекспериментальний зріз, метою якого було визначення підсумкового рівня сформованих умінь студентів-дизайнерів 3-го курсу КНУТД продукувати монолог-презентацію-доповідь і -рекламу. Спосіб і завдання зрізу мали той самий характер, що і передекспериментальний зріз, але завдання були розроблені на іншому мовному матеріалі. Завданням усного післяекспериментального зрізу було самостійне продукування студентами-дизайнерами монологу-презентації згідно з вивченим матеріалом за модулями.

Коефіцієнт навченості за результатами післяекспериментального зрізу складає для монологу-презентації-доповіді в ЕГ-1 - 0,70, у ЕГ-2 - 0,72; для монологу-презентаціїреклами в ЕГ-1 - 0,78, у ЕГ-2 - 0,82.

При порівнянні передекспериментальних і післяекспериментальних показників зафіксовано значний прогрес в оволодінні студентами експериментальних груп навичками й уміннями створення монологу-презентації-доповіді й -реклами. Дані результати свідчать, що запропонований комплекс вправ для професійно орієнтованого навчання англомовного монологу-презентації $є$ ефективним. На рис. 1 и рис. 2 наведено приріст навичок і вмінь 
студентів продукувати монолог-презентацію-доповідь і -рекламу згідно 3 результатами перед- і післяекспериментальних зрізів.

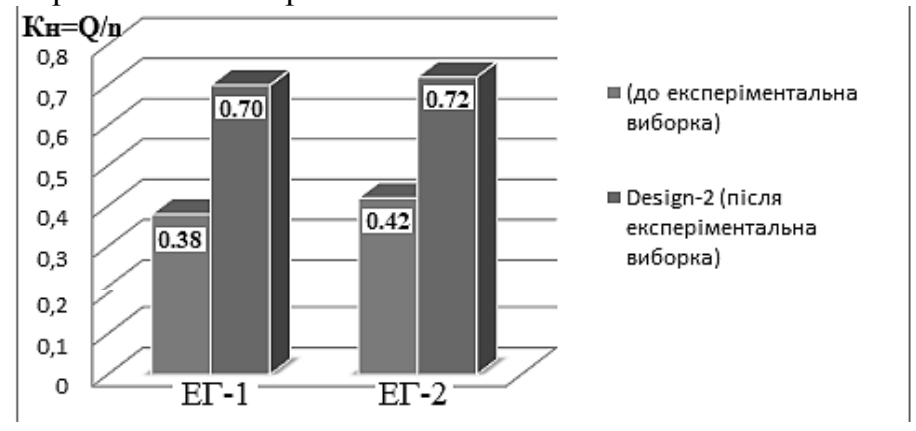

Рис. 1. Гістограми приросту коефіцієнта навченості укладати монолог-доповідь за результатами до- і післяекспериментального зрізів

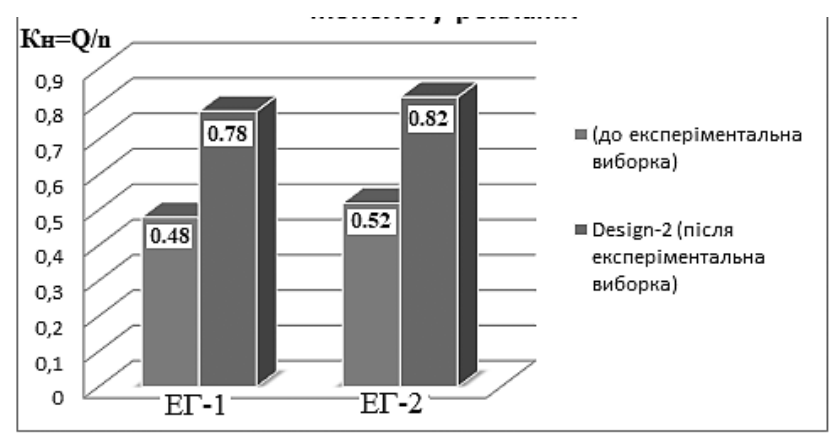

Рис. 2. Гістограми приросту коефіцієнта навченості укладати монолог-рекламу за результатами до- і післяекспериментального зрізів

Отже, середній показник приросту навичок і вмінь створювати монолог-презентаціюдоповідь і -рекламу складає 0,30. Ці дані свідчать про ефективність двох варіантів запропонованої методики (варіант А - “зверху-униз”, варіант Б - “знизу-уверх”). Середній показник рівня сформованості вмінь створювати монолог-презентацію-доповідь склав 0,70, за В. П. Беспальком. Тому ми вважаємо для навчання монологу-презентації-доповіді ефективним варіант А. Середній показник рівня сформованості вмінь створювати монологпрезентацію-рекламу склав 0,80 , тому для навчання монологу-презентації-реклами ми вважаємо найефективнішим варіант Б. Для підтвердження вірогідності цих даних і для оцінки максимальної їх надійності здійснено математичний аналіз. Перевірено достовірність отриманих результатів за допомогою критерію $\varphi^{*}$, де $\varphi^{*}-$ кутове перетворення Фішера.

Для того щоб зрозуміти, який із варіантів запропонованої методики навчання майбутніх дизайнерів монологу-презентації є найефективнішим, сформулюємо статистичні гіпотези. Оскільки в обох експериментальних групах всі учасники експерименту досягли рівня навченості за В. П. Беспальком та під час навчання монологу-презентації-реклами був досягнутий коефіцієнт навченості 0,80 , то в межах нашого дослідження ми вважаємо цей коефіцієнт навченості “ефектом”, а недосягнення цього коефіцієнта - “відсутністю ефекту”.

Сформулюємо дві статистичні гіпотези: $\mathrm{H}_{0}$ : частка осіб, які досягли коефіцієнта навченості 0,8 в навчанні монологу-презентації, в ЕГ-2 - не білыша, ніж в ЕГ-1; $\mathrm{H}_{1}$ : частка осіб, які досягли коефіцієнта навченості 0,8 в навчанні монологу-презентації, в ЕГ-2 більша, ніж в ЕГ-1.

За результатами підрахунків, якщо отримане емпіричне значення $\varphi^{*}$ міститься в зоні значущості, підтверджується гіпотеза $\mathrm{H}_{1}$; якщо $\varphi^{*}$ розміщення в зоні незначущості, 
підтверджується гіпотеза $\mathrm{H}_{0}$. Результати наведено в табл. 3 .

Таблиия 3

Таблиця для підрахунку $\varphi^{*}$ з метою визначення ефективнішої методики навчання монологу-презентації майбутніх дизайнерів

\begin{tabular}{|c|c|c|c|c|c|c|c|}
\hline & \multicolumn{3}{|c|}{ "с ефект" } & \multicolumn{3}{|c|}{ "немас ефекту" } & \\
\hline Групи & $\begin{array}{l}\text { Кількість } \\
\text { студентів }\end{array}$ & $\begin{array}{l}\text { Процентна } \\
\text { частка }\end{array}$ & $\varphi^{*}$ & $\begin{array}{l}\text { Кількість } \\
\text { студентів }\end{array}$ & $\begin{array}{c}\text { Процентна } \\
\text { частка }\end{array}$ & $\varphi^{*}$ & $\begin{array}{l}\text { Загальна } \\
\text { кількість } \\
\text { студентів }\end{array}$ \\
\hline EГ-1 & 7 & $53,8 \%$ & 1,69 & 6 & $46,2 \%$ & 1,45 & 13 \\
\hline ЕГ-2 & 12 & $92,3 \%$ & 2,89 & 1 & $7,7 \%$ & 0,24 & 13 \\
\hline
\end{tabular}

За результатами даних $\varphi_{\mathrm{emn}}^{*}=3,08$. Порівняємо отримане значення з $\varphi_{\mathrm{kp}}^{*}$.

$$
\varphi_{\mathrm{kp}}^{*}=\left\{\begin{array}{l}
1,64(p \leq 0,05) \\
2,31(p \leq 0,01)
\end{array}\right.
$$

На рис. 3 побудовано вісь “значущості”.

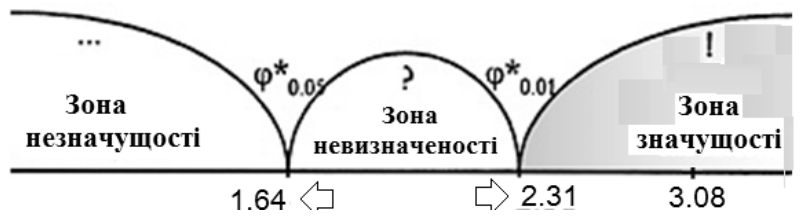

Рис. 3 Вісь значущості

Отже, результат потрапив до зони значущості. Це свідчить про те, що гіпотеза $\mathrm{H}_{0}$ відкидається. Таким чином, ми дійшли висновку, що кількість студентів, які досягли рівня коефіцієнта навченості за результатами післяекспериментального зрізу, в ЕГ-2 більша, ніж в ЕГ-1. Ці дані дають нам підстави стверджувати, що ефективність методики навчання майбутніх дизайнерів монологу-презентації є вищою.

Перевірена нами ефективність запропонованої методики дала змогу визначити достовірність нашого експерименту. Це свідчить, що ця методика навчання професійно орієнтованого англомовного монологу-презентації-доповіді й -реклами сприяє підвищенню рівня сформованості вмінь студентів продукувати монолог-презентацію англійською мовою.

Висновки і перспективи подальших розвідок. Проведений експеримент довів, що розроблена методика виявилася ефективною і може буги рекомендована для впровадження в освітній процес. Перспективу подальших розвідок вбачаємо у моделюванні процесу навчання майбутніх дизайнерів нелінгвістичних закладів вищої освіти.

\section{ЛІТЕРАТУРА}

Беспалько, В. П. (1968). Опыт разработки и использования критериев качества усвоения знаний. Советская педагогика, 4, 52-69.

Гурвич, П. Б. (1980). Теория и практика эксперимента в методике преподавания иностранных языков (спеикурс). Владимир, СССР: Издательство Владимирского педагогического институга.

Корнєєва, I. О. (2017). Аналіз сучасного стану формування професійно орієнтованої англомовної компетентності в монологічному мовленні майбутніх дизайнерів. Вісник Київського національного лінгвістичного університету, Серія: Педагогіка та психологія, $26,113-122$.

Korneyeva, I. (2017). The stages of professionally-oriented monologue-presentation training of future designers and according system of exercises. Педагогічні науки: теорія, історія, 
інноваційні технологї̈, 9(73), 86-97. DOI 10.24139/2312-5993/2017.09/086-097.

\section{REFERENCES}

Bespal'ko, V. P. (1968). Opyt razrabotki i ispol'zovanija kriteriev kachestva usvoenija znanij. Sovetskaja pedagogika, 4, 52-69.

Gurvich, P. B. (1980). Teorija i praktika jeksperimenta v metodike prepodavanija inostrannyh jazykov (speckurs). Vladimir, SSSR: Izdatel'stvo Vladimirskogo pedagogicheskogo instituta.

Korneyeva, I. (2017). The stages of professionally-oriented monologue-presentation training of future designers and according system of exercises. Pedahohichni nauky: teoriia, istoriia, innovatsijni tekhnolohii, 9(73), 86-97. DOI 10.24139/2312-5993/2017.09/086-097. 